\title{
GEOLOGIA E GEOQUÍMICA DO PLUTÃO SHOSHONÍTICO DE TERRA NOVA: EVIDÊNCIAS DE MAGMATISMO PROTEROZÓICO DE PRESSÃO. MÉDIA NA PROVÍNCIA BORBOREMA
}

\author{
ADEJARDO F. SILVA, F* e IGNEZ P. GUIMARÃES*
}

\begin{abstract}
GEOLOGY AND GEOCHEMISTRY OF THE SHOSHONITIC TERRA NOVA PLUTON, PE: EVIDENCE OF MEDIUM PRESSURE PROTEROZOIC MAGMATISM IN THE BORBOREMA PROVINCE. The Terra Nova shoshonitic pluton is intruded in the metamorphic Proterozoic rocks of the Cachoeirinha-Salgueiro belt, in the Pernambuco state, close to the Pernambuco lineament. It is comprised of porphyritic leucocratic quartz syenites and syenites, and mesocratic syenites. The latter is included by the host leucocratic syenites. It was observed decrease of alkaline feldspar and hornblende granulation, from north to south. The alkaline feldspars from the leucocratic syenites and those from the mesocratic syenites show similar composition and zoning for $\mathrm{BaO}$. The amphiboles are respectively edenite, edenitic homblend and actinolite. The epidote group minerals are zoisite and epidote. Petrographic evidence shows that some epidote crystals were formed before the alkaline feldspar and the biotite. They seem to be contemporaneous to some of the hornblende crystals. The evidences point to either a magmatic origin or a sub-solidus one for these epidote crystals. Data obtained from the calcic amphibole geobarometer suggest respectively a minimum pressure for the Terra Nova pluton of $1,2 \mathrm{kbar}$ and a maximum pressure of 4,7 kbar. Petrographic and field evidences show that the Terra Nova pluton was intruded under the tectonic control of the Pernambuco lineament. The deformation have reached the pluton during its cooling stage. There is also evidence that Pernambuco lineament reactivation after the Terra Nova pluton cooling caused local retrogressive metamorphism and shear fractures. The Terra Nova pluton represents a shoshonitic upper Proterozoic magmatism, intruded under at maximum medium pressure.
\end{abstract}

Keywords: Brasiliano magmatism, shoshonitic magmatism, medium pressure.

RESUMO O plutão shoshonítico de Terra Nova está intrudido em rochas metamórficas proterozóicas a SW do Cinturão Cachoeirinha-Salgueiro, no Estado de Pernambuco, próximo ao lineamento Pernambuco. É constituído principalmente por quartzo-sienitos e sienitos porfiríticos e leucocráticos. Secundariamente, ocorre uma suíte de sienitos mesocráticos de granulação fina, incluídos pelas hospedeiras leucocráticas. Foi observada uma gradação do tamanho dos cristais de feldspatos alcalinos e da hornblenda, de norte para sul, dentro do plutão. Os feldspatos alcalinos das fácies leucocráticas possuem composição e padrão de zoneamento para $\mathrm{BaO}$ muito semelhante com aqueles dos sienitos mesocráticos. Os anfibólios possuem composição respectivamente edenítica, hornblenda edenítica e actinolítica. Os minerais do grupo do epídoto são, respectivamente, epídoto e zoisita. Evidências petrográficas indicam que alguns epídotos são anteriores aos feldspatos alcalinos e à biotita, parecendo ser contemporâneos a alguns dos minerais de hornblenda. As evidências que apontam para uma origem magmática ou uma origem durante o estado sab-solidus ainda são inconclusivas. Dados obtidos a partir do geobarômetro de anfibólio cálcico sugerem, respectivamente, pressão mínima de intrusão do plutão de Terra Nova de 1,2 kbar e pressão máxima de 4,7 kbar. Evidências petrográficas e de relações de campo indicam que o plutão de Terra Nova foi intrudido sob o controle estrutural do Lineamento Pernambuco. A deformação teria atingido o plutão antes do completo resfriamento do mesmo. Evidências texturais e de campo também indicam que houve uma reativação do lineamento após o resfriamento total do plutão de Terra Nova, causando retrometamorfismo na fácies xistoverde e fraturas de cisalhamento segundo faixas miloníticas estreitas no setor SW do plutão. Portanto, o plutão de Terra Nova representa um magmatismo shoshonítico brasiliano, intrudido no máximo a uma pressão média, durante uma fase da orogênese Brasiliana na qual o Lineamento Pernambuco estava ativo.

Palavras-chaves: Magmatismo brasiliano, magmatismo shoshonitico, pressão média.

INTRODUÇÃO O plutão de Terra Nova possui composição shoshonítica (Silva et al 1987) e características dos granitóides tipo Itaporanga (Almeida et al 1967) ou granitóides ricos em potássio (Sial 1984). A importância destes granitóides deve-se ao fato de, no mundo, eles estarem freqüentemente associados a depósitos de cobre pórfiro (Nardi 1986), e geotectonicamente estarem freqüentemente localizados acima das zonas de subducção (Thompson \& Fowler 1986).

Na Província Borborema, os plutões shoshoníticos têm sido identificados no Cinturão Cachoeirinha-Salgueiro (Silva et al 1987, Mariano \& Sial 1988), no Cinturão Pajeú-Paraíba (Guimarães et al 1988) e no Cinturão Sergipano. Inferência a partir do mapa publicado por Sial (1987) sugere que eles ocupam ambos os flancos do Cinturão Cachoeirinha-Salgueiro, e o flanco sul do Cinturão Pajeú-Paraíba. O conhecimento dos mesmos no Cinturão Sergipano ainda está na fase preliminar.
O presente trabalho fornece e discute alguns dados de natureza geológica, geoquímica e mineralógica, para melhor esclarecer o posicionamento tectônico do plutão de Terra Nova, que intrude metamorfitos do Cinturão CacheoirinhaSalgueiro.

GEOLOGIA REGIONAL O plutão de Terra Nova se localiza no extremo sudoeste do Cinturão Cachoeirinha-Salgueiro (Fig. 1), intrudindo a seqüência metavulcanossedimentar do mesmo. O referido cinturão foi definido pela primeira vez por Brito Neves (1975) e denominado, então, como Piancó-Alto Brígida. Tal denominação foi modificada por Sial (1986) para Cachoeirinha-Salgueiro, em referência às principais seqüências metavulcanossedimentares que ocorrem no cinturão.

O Cinturão Cachoeirinha-Salgueiro situa-se entre dois maciços medianos, respectivamente Rio Piranhas, a norte, e Per- 


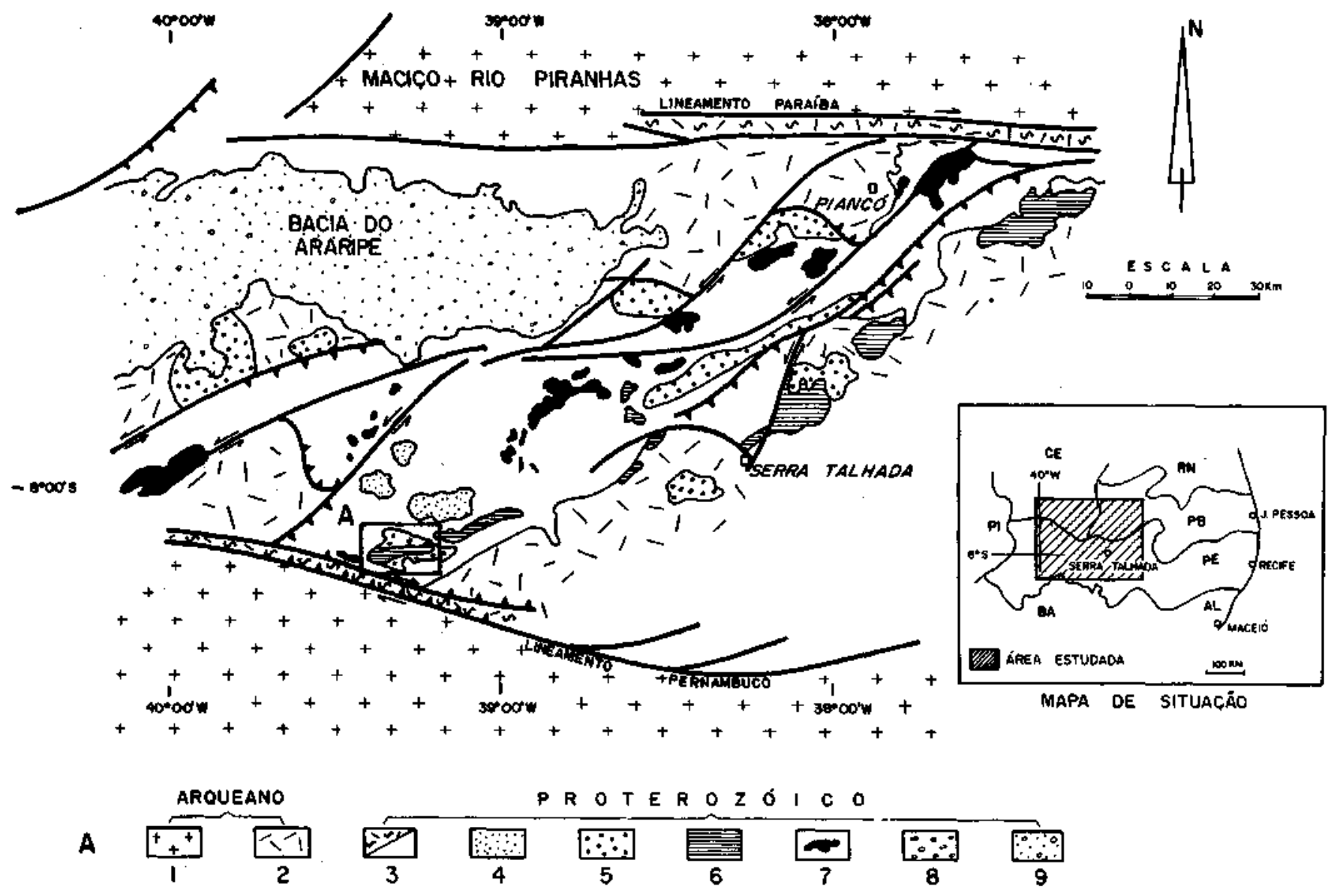

Figura 1 - Esboço geológico do cinturão Cachoeirinha-Salgueiro, modificado a partir de Silva (1985) e Sial (1986). Símbolos usados na legenda: 1. Rochas do maciço mediano PE-AL; 2. Grupo Bom Nome; 3. Grupos Cachoeirinha e Salgueiro indiferenciados, e rochas cataclásticas dos Lineamentos Pernambuco e Paraíba; 4. Plutões cálcio-alcalinos ricos em potássio (tipo Serrita); 5. Plutões shoshoníticos (tipo Itaporanga); 6. Plutões peralcalinos e ultrapotássicos (tipo Catingueira); 7. Plutões cálcio-alcalinos (tipo Conceição); 8. Molassas; 9. Bacia sedimentar do Araripe; A. Area de estudo

Figure 1 - Geologic sketch of the Cachoeirinha-Salgueiro Belt, modified from Silva (1985) and Sial (1986). Symbols used in the caption: 1. PE-AL Median Massif rocks; 2. Bom Nome Group; 3. Cachoeirinha-Salgueiro Groups, and cataclastic rocks from Pernambuco e Paraíba Lineaments; 4. K-rich Calc-alkaline plutons (Serrita type); 5. Shoshonitic plutons (Itaporanga type); 6. Peralkaline and ultrapotassic plutons (Catingueira type); 7. Calc-alkaline plutons (Conceição type); 8. Molasses; 9. Araripe Sedimentar Basin; A. Studied area

nambuco-Alagoas, ao sul, onde predominam rochas de idade Arqueana (Brito Neves 1975). Possui em torno de $20.000 \mathrm{~km}^{2}$ (300 km de comprimento por $70 \mathrm{~km}$ de largura em média), e limita-se a norte e a sul por lineamentos de extensão continental, respectivamente Lineamento Paraíba e o Lineamento Pernambuco. Cortando longitudinalmente o cinturão, ocorrem falhas de rejeito direcional e falhas de empurrão. $\mathrm{O}$ cinturão é intrudido predominantemente por rochas graníticas, agrupadas por Sial (1986) segundo quatro tipos de plutões: cálcio-alcalinos ricos em potássio (tipo Serrita), shoshoníticos (tipo Itaporanga), peralcalinos e ultrapotássicos (tipo Catingueira) e os cálcio-alcalinos (tipo Conceição). O plutão de Terra Nova se assemelha àqueles denominados tipo Itaporanga.

Silva (1985) descreveu o Cinturão Cachoeirinha-Salgueiro como sendo constituído pelos Grupos Cachoeirinha e Salgueiro, que repousam sobre o Grupo Bom Nome, e uma unidade molassóide. Os Grupos Cachoeirinha e Salgueiro possuem litologias semelhantes, diferindo basicamente quanto ao grau metamórfico a que foram submetidos (Lima 1989).

Dados recentes, a partir da geologia e geoquímica de rochas graníticas (Silva 1989) e de geoquímica de metassedimentos (Lima 1989), apontam para uma evolução do referido cinturão como margem continental ativa durante o Proterozóico Superior, já que idades de rochas meta vulcânicas félsicas encai- xadas no Grupo Cachoeirinha obtidas por Brito Neves et al (1990) são de 1,1 Ga.

RELAÇÕES DE CAMPO O plutão de Terra Nova intrude as unidades 1 e 2 do Grupo Salgueiro, de acordo com a subdivisão proposta por Silva (1985), e é intrudido pelo plutão Serra do Livramento (Fig. 2) e por um enxame de diques de composição ultrapotássica (Silva 1989).

A unidade 1 do Grupo Salgueiro é constituída por cristas quartzíticas e forma a base da seqüência. A unidade 2 se sobrepõe à unidade 1 e consiste de mica xistos e metavulcânicas. Os mica xistos possuem clorita, biotita, quartzo, granada, feldspato e magnetita. As rochas metavulcânicas são atualmente representadas por anfibolitos, ocorrendo próximos à localidade de Boqueirão, vizinhas ao contato sul do Plutão de Terra Nova.

A geologia do plutão de Terra Nova foi descrita anteriormente em detalhe (Silva et al 1987). Ele é constituído principalmente por quartzo sienitos e sienitos, porfiríticos e leucocráticos. O plutão engloba duas suítes distintas de xenólitos, uma das quais considerada como de natureza co-genética em relação à hospedeira (Silva 1989) e denominada de sienitos mesocráticos, e a segunda constituída por várias rochas metamórficas. 

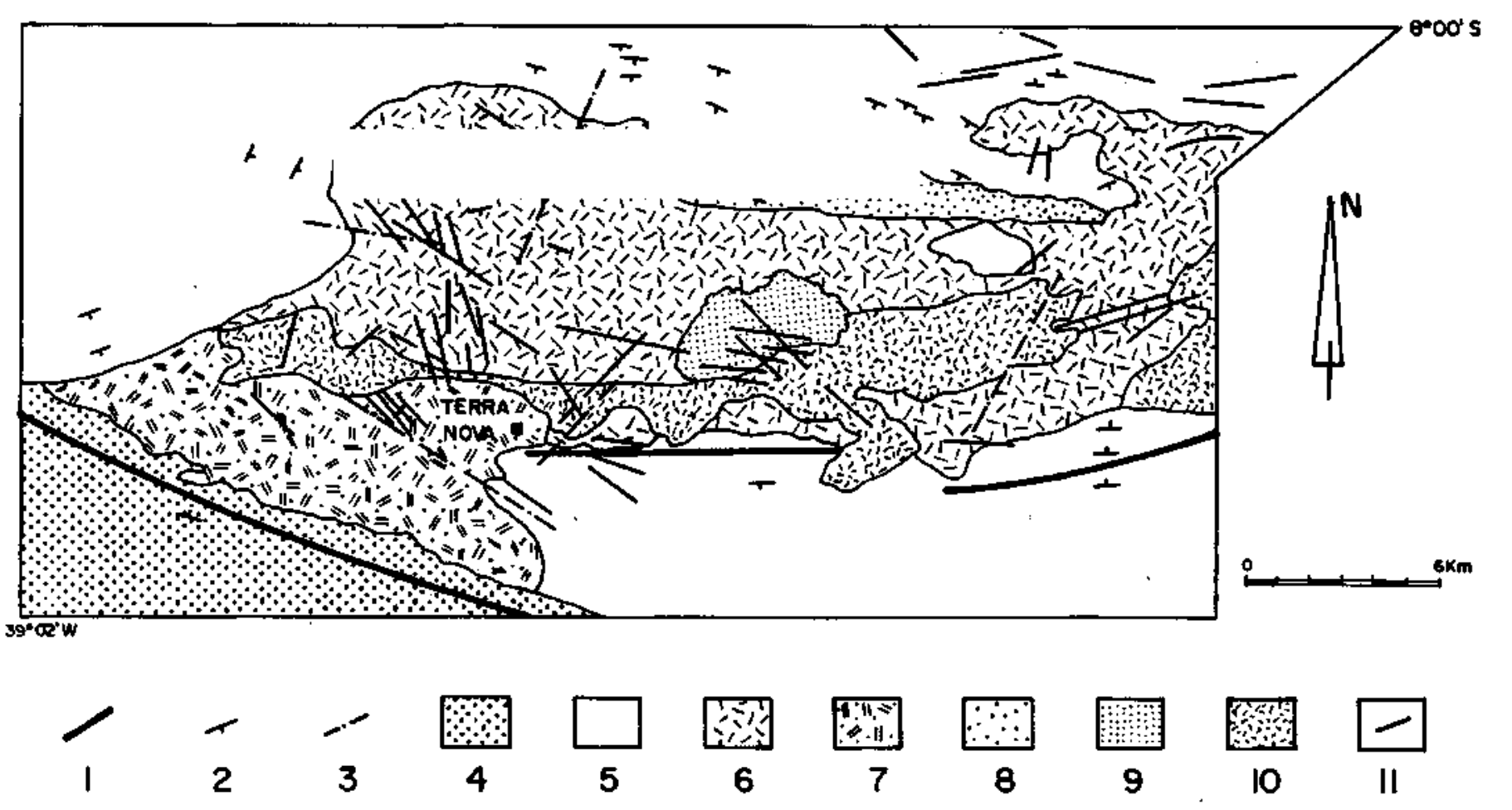

Figura 2 - Mapa geológico da região de Terra Nova. Símbolos usados na legenda: 1. Falhas; 2. Foliações; 3 . Fraturas; 4. Grupo Bom Nome; 5. Grupos Cachoeirinha e Salgueiro indiferenciados; 6. Hornblenda sienito grosso; 7. Hornblenda sienito de grosso a fino; 8. Hornblenda sienito muito grosso; 9. Quartzo sienito; 10. Plutão Serra do Livramento; 11. Diques ultrapotassicos

Figure 2 - Geologic map of the Terra Nova region. Symbols used in the caption: 1. Faults; 2. Foliation; 3. Fractures; 4. Bom Nome Group; 5. Cachoeirinha-Salgueiro Groups; 6. Coarse hornblende syenite; 7. Coarse to fine hornblende syenite; 8. Very coarse hornblende syenite; 9. Quartz syenite; 10. Serra do Livramento pluton; 11. Ultrapotassic dykes

Quatro fácies leucocráticas e uma suíte composta por inclusões leucocráticas foram descritas no plutão de Terra Nova a saber (Fig. 2): 1. Hornblenda sienito muito grosso; 2. Hornblenda sienito grosso; 3. Quartzo sienito de médio a grosso; 4. Hornblenda sienito de médio a fino. A distribuição das referidas fácies está apresentada na figura 2.

O mapeamento das fácies foi realizado com base na variação do tamanho dos minerais, na estimativa do teor modal de quartzo, feldspato e homblenda, na diferença do padrão de deformação, e em feições observadas próximo aos contatos. As fácies leucocráticas e as inclusões leucocráticas são descritas a seguir:

1. Hornblenda sienito muito grosso - esta fácies ocorre ao longo da borda norte do plutão, segundo uma faixa paralela à mesma, e é considerada como a fácies menos deformada tectonicamente entre aquelas que foram mapeadas. $\mathrm{O}$ contato entre esta fácies e as adjacentes tem sido considerado como gradacional.

2. Hornblenda sienito grosso - esta fácies é considerada como a mais abundante em termos de área aflorante, ocorrendo ao norte do Plutão Serra do Livramento e no setor SW do plutão. 3. Quartzo sienito de médio a grosso - ocupa a parte central do plutão, próximo ao contato entre o mesmo e o plutão Serra do Livramento. Apresenta poucas evidências de deformação e inclui grande número de inclusões mesocráticas.

4. Hornblenda sienito de médio a fino - esta fácies é encontrada apenas na parte SW do plutão, ocorrendo como pseudodiques, similares àqueles descritos por Pitcher \& Bussel (1985) no Batólito do Peru. Quando ocorre como pseudodiques, é incluída por hornblenda sienito grosso. Por outro lado, pode ocorrer em alguns afloramentos como a fácies principal, incluindo rochas da fácies hornblenda sienito grosso. Os contatos dela com as fácies adjacentes variam de contatos bruscos a subgradacionais. O conjunto aparenta ter sido dobrado num estado plástico. Isto sugere que a intrusão das diferentes fácies ocorreram sob um alto strain, $e$ antes da completa consolidação das fácies mais primitivas.

5. Inclusões leucocráticas - são constituídas unicamente por feldspatos brancos ou creme e, às vezes, biotita. Possuem textura variável, de fina a média, que sempre contrasta com a da rocha hospedeira. Os grãos minerais alcançam até $1 \mathrm{~cm}$ de dimensão máxima. Possuem forma redonda, diâmetro máximo de $5 \mathrm{~cm}$ e contato nítido com a hospedeira. Não foi possível a coleta de amostras das mesmas.

Os sienitos mesocráticos são constituídos por inclusões que variam, em composição, de básica a intermediária (Silva 1989), mas a maioria estudada apresenta composição básica. As inclusões, de uma maneira geral, apresentam tamanho e forma bastante variada, de $0,05 \mathrm{~m}$ a $1 \mathrm{~m}$ de comprimento, perfil oval, arredondado, quadrado ou elíptico. O perfil elíptico é o mais comum. Os contatos com as hospedeiras são bruscos e, às vezes, podem ser marcados por uma nítida borda de reação. As referidas bordas de reação compõem-se de biotita e anfibólio verde. Inclusões compostas (inclusão de composição intermediária contida por outra de composição ácida) foram identificadas em alguns afloramentos, ou com grande ou com muito pequena diferença composicional entre elas. No local onde o plutão apresenta foliação, as inclusões são concordantes com a mesma.

Embora raras, foram identificadas inclusões leucocráticas, que apresentam variação textural entre equigranular com granulação fina, a porfirítica com granulação fina. São, em geral, elípticas ou quase redondas e não apresentam bordas de reação.

Os contatos entre o plutão de Terra Nova e as encaixantes são, em geral, concordantes com os traços da foliação regional 
(Fig. 2). As relações de contato com as encaixantes são melhor observáveis na parte centro-sul, onde o contato é brusco e delineado por uma faixa de cataclasitos. Feições similares foram observadas pelos autores na parte SW do plutão, onde ocorrem fenocristais de feldspato rotacionados dextralmente. Eles ocorrem no contato entre o plutão e as encaixantes. O sentido da rotação registrado pelos feldspatos é concordante com o caráter dextral do Lineamento Pernambuco. As foliações observadas no setor SW do plutão são definidas por biotita e/ou hornblenda. A direção da foliação varia entre 234 az e $10 \mathrm{az}$, e o mergulho entre $30^{\circ}$ e $80^{\circ}$.

PETROGRAFIA De acordo com as recomendações da International Union of Geological Sciences (IUGS) (Streckeisen 1976) e as composições modais listadas na tabela 1, as rochas do plutão de Terra Nova foram classificadas como sienitos e quartzo-sienitos.

1. Fades leucocráticas A fácies leucocrática é constituído pelas rochas de granulação grossa a muito grossa, que constituem a quase totalidade do Plutão de Terra Nova, e de raras e pequenas inclusões leucocráticas.

As rochas de granulação grossa a muito grossa contêm feldspatos alcalinos que variam de tamanho entre 1,5 e 5,0 $\mathrm{cm}$. Isto faz com que a contagem de pontos em seção delgada não seja possível. Portanto, foi utilizada uma combinação de estimativa visual em afloramento e em seções de amostra de mão, polidas e coloridas.

A partir da geologia de campo, da petrografia e, como será visto posteriormente, dos dados geoquímicos, fica evidente que as rochas que constituem as fácies leucocráticas, com exceção das inclusões leucocráticas, são consangüíneas. Para se evitar repetições, os dados petrográficos e mineralógicos das fácies leucocráticas são discutidos em conjunto.

Os sienitos e quartzo-sienitos do plutão de Terra Nova são, na maioria, porfiríticos, com fenocristais de feldspatos alcalinos, hornblenda e, às vezes, plagioclásio. A matriz é constituída por pertita, biotita, quartzo, apatita, epídoto, titanita e allanita.

Os feldspatos alcalinos são, em geral, subeudrais e, às vezes, circundados por mirmequitas. São principalmente microclínio pertítico, na maioria das vezes poiquilítico, incluindo biotita, hornblenda, titanita, quartzo, allanita e plagioclásio. Ocorrem levemente deformados ou não-deformados. Aqueles não-deformados não apresentam qualquer indício de terem sido recristalizados. As estimativas modais indicam que o feldspato alcalino totaliza entre 60 e $80 \%$. Os fenocristais de feldspato alcalino mostram nítido decréscimo de tamanho de norte para sul, acompanhando o aumento da deformação dentro do plutão, da seguinte maneira: 1. No extremo norte do plutão, possuem até $5,0 \mathrm{~cm}$ de comprimento, nos hornblenda sienitos muito grossos; 2 . No setor centro-norte do plutão, apresentam até $2,0 \mathrm{~cm}$ de comprimento, constituindo os hornblenda sienitos grossos; 3. Nos homblenda-quartzo sienitos, que ocupam a porção central do plutão, eles alcançam até 1,5 $\mathrm{cm}$ de comprimento; 4. Finalmente, no setor mais deformado do plutão (parte SW do mesmo onde ocorrem hornblenda sienitos médios e finos), apresentam no máximo $0,5 \mathrm{~cm}$ de comprimento.

Os fenocristais de hornblenda também são subeudrais e poiquilíticos. As inclusões são constituídas por apatita, opacos, quartzo, titanita, biotita e raramente zircão. Os fenocristais de hornblenda apresentam diminuição de granulação, de norte para sul, da seguinte maneira. 1. Hornblenda sienitos muito grossos - atingem até 1,5 cm de comprimento; 2 . Hornblenda sienitos grossos - atingem até $1,0 \mathrm{~cm}$ de comprimento; 3. Hornblenda-quartzo sienitos - atingem até 0,7 $\mathrm{cm} ; 4$. Hornblenda sienitos de médio a fino - atingem 0,3 cm de comprimento.

Os plagioclásios ocorrem principalmente na matriz e apenas ocasionalmente como fenocristais. As inclusões de biotita nos plagioclásios tendem a formar zonas concêntricas em relação às bordas do cristal. A porcentagem modal do plagioclásio é em torno de 7\% (Tab. 1).

Tabela 1 - Análises modais dos hornblenda sienitos finos do plutão de Terra Nova

Table 1 - Modal analysis of the fine grained hornblende syenites from the Terra Nova Pluton

\begin{tabular}{l|rrr}
\hline \multicolumn{1}{c|}{ AMOSTRA } & $248-\bar{A}$ & \multicolumn{1}{c}{253} & 255-C \\
\hline Quartzo & 17,68 & 12,44 & 3,34 \\
Feldspato alcalino & 42,26 & 58,55 & 44,65 \\
Plagioclásio & 7,24 & 0,86 & 0,17 \\
Anfibólio & 26,26 & 23,66 & 49,67 \\
Biotita & 4,88 & 1,90 & 1,51 \\
Titanita & 0,84 & 0,35 & 0,33 \\
Epidoto & 0,51 & 0,00 & 0,17 \\
Opacos & 0,34 & 2,25 & 0,17 \\
\hline
\end{tabular}

Os feldspatos alcalinos pertíticos são encontrados principalmente na matriz e às vezes como fenocristais.

$\mathrm{O}$ quartzo ocorre restrito à matriz, como grãos isolados, ou em intercrescimentos mirmequíticos circundando os fenocristais de feldspato alcalino, segundo porcentagem modal variando entre 5 e $10 \%$ (Tab. 1).

Titanita ocorre como cristais isolados, euedrais e de tamanho variado. Apatita ocorre como cristais subedrais ou euedrais, em geral inclusa em hornblenda, biotita e feldspatos. Alguns dos cristais de zircão parecem mostrar um padrão de zoneamento oscilatório.

Allanita ocorre como pequenos grãos zonados, algumas vezes com bordos de epídoto. Pode estar incluída em hornblenda, biotita, titanita, epídoto e feldspato alcalino.

Epídoto ocorre na matriz da maioria das amostras estudadas, como cristais euedrais ou subedrais. Quando são subedrais, estão associados com biotita, hornblenda e titanita. Quando anedrais, estão incluídos por feldspatos alcalinos. 2. Fácies Mesocráticas As rochas que constituem a fácies mesocrática apresentam alta porcentagem de minerais máficos (valor médio de $60,5 \%$ ). Usando a classificação proposta pela IUGS e as composições modais listadas na tabela 2, estas rochas são classificadas como sienitos. Entretanto, devido a alta porcentagem modal de minerais máficos, preferiu-se a denominação sienito mesocrático.

São rochas em geral equigranulares, embora textura porfirítica ocorra localmente com fenocristais de feldspato alcalino ou hornblenda. Uma assembléia mineral típica inclui

Tabela 2 - Análises modais dos sienitos mesocráticos do plutão de Terra Nova

Table 2 - Modal analysis of the mesocratic syenites from the Terra Nova Pluton

\begin{tabular}{l|rrrrr}
\hline \multicolumn{1}{c|}{ AMOSTRA } & 216-B & $213-\mathrm{B}$ & $\mathbf{2 2 0 - \mathrm { B }}$ & $244-\mathrm{B}$ & $235-\mathrm{B}$ \\
\hline Quartzo & 13,05 & 15,45 & 18,29 & 2,67 & 5,65 \\
Feldspato alcalino & 23,16 & 17,95 & 12,44 & 32,65 & 35,89 \\
Plagioclásio & 6,32 & 2,50 & 7,80 & 3,29 & 0,40 \\
Anfibólio & 24,42 & 40,22 & 38,54 & 25,67 & 25,60 \\
Biotita & 10,11 & 12,95 & 7,56 & 27,52 & 18,55 \\
Titanita & 0,84 & 1,14 & 1,46 & 0,00 & 0,00 \\
Epidoto & 3,58 & 1,59 & 1,95 & 0,00 & 0,00 \\
Clinopiroxênio & 18,53 & 0,00 & 0,00 & 0,00 & 0,00 \\
\hline
\end{tabular}


homblenda, actinolita, biotita, plagioclásio, feldspato alcalino, quartzo, titanita, apatita, allanita, clinopiroxênio e minerais opacos.

O feldspato alcalino e a homblenda são as fases predominantes no sienito mesocrático. Os feldspatos alcalinos podem ocorrer ora como fenocristais subedrais ora na matriz. Alguns raros grãos de clinopiroxênio verde-claro ocorrem, contendo inclusões de biotita, anfibólio, feldspato alcalino e epídoto. Os cristais de epídoto variam de subedral a euedral e ocorrem em porcentagem modal entre $\mathrm{O}$ e $14 \%$. Apatita ocorre como acículas ou como cristais euedrais.

QUÍMICA MINERAL Foram analisados 26 cristais de feldspato alcalino das fácies leucocráticas e dos sienitos mesocráticos por microssonda eletrônica equipada com EDS no Imperial College, Londres. Os cristais foram sistematicamente analisados no núcleo e na borda, e no caso dos fenocristais fortemente zonados, foram realizados perfis transversais do núcleo para a borda do cristal.

Algumas análises representativas de núcleos de cristais são mostradas na tabela 3 . Os feldspatos alcalinos das fácies leucocráticas variam em composição de $\mathrm{Ab}_{3} \mathrm{An}_{1} \mathrm{Or}_{96}$ a $\mathrm{Ab}_{32} \mathrm{An}_{0} \mathrm{Or}_{68}$. Os feldspatos alcalinos dos sienitos mesocráticos variam de $\mathrm{Ab}_{6} \mathrm{An}_{1} \mathrm{Or}_{93}$ a $\mathrm{Ab}_{14} \mathrm{An}_{1} \mathrm{Or}_{85}$. As análises obtidas revelam um zoneamento normal marcante de $\mathrm{Na}_{2} \mathrm{O}$ e $\mathrm{BaO}$, com teores de $\mathrm{BaO}$ aumentando do núcleo para a borda do cristal.

Apesar dos feldspatos alcalinos das duas suítes apresentarem diferenças em termos de relações texturais e de granulação, apresentam composição química similar e mesma variação de teores de $\mathrm{BaO}$.

Os plagioclásios das fácies maiores e das inclusões mostram composição variando entre andesina e albita (Fig. 3).

Foram realizadas aproximadamente 60 análises em anfibólios do plutão de Terra Nova por microssonda eletrônica, seguindo a mesma sistemática e metodologia utilizada no caso dos feldspatos alcalinos. Algumas análises representativas de núcleos de cristais estão na tabela 4 . A classificação e o cálculo dos membros extremos foram realizados segundo Leake (1978). As reações ferro (II)/ferro (III) foram estimadas utilizando-se o programa Minfile (Afifi \& Essene 1978).

Os anfibólios das fácies leucocráticas são principalmente edenita e homblenda edenítica (Fig. 4), enquanto aqueles dos sienitos mesocráticos são principalmente actinolita e raramente edenita e homblenda edenítica (Tab. 4).
Os anfibólios actinolíticos ocorrem principalmente nos membros básicos dos sienitos mesocráticos e, menos freqüentemente, nas fácies leucocráticas. Ocorrem principalmente como bordas na edenita e homblenda edenítica. $\mathrm{O}$ contato entre estes minerais é, em geral, gradacional.

GEOBAROMETRIA COM EPÍDOTO O epídoto está geralmente associados com metamorfismo dinâmico retrogressive e também é encontrado, na ausência de shear stress, como produto de saussuritização do plagioclásio (Deer et al 1966). Vários autores têm levantado a possibilidade de que epídoto pode ocorrer em rochas ígneas como uma fase primária tardia (Whitney et al 1976, Crawford \& Hollister 1982, Zen \& Hammarstron 1984). Whitney et al (1976) estimou que o epídoto poderia ser estável, em equilíbrio com um fundido anatético a aproximadamente $650^{\circ}$ e 3,5 kbars, sob condições de alta fugacidade do oxigênio (próxima ao buffer hematita/magnetita). Baixos valores da fugacidade de oxigênio impediram que a estabilidade do epídoto alcançasse a linha do solidus até uma pressão próxima a 8 kbar. Crawford \& Hollister (1982) estimam 6 kbar como a pressão mínima para a existência de epídoto magmático.

Naney (1983), trabalhando com material sintético de composição granodiorítica, a pressões entre 2 e $8 \mathrm{kbar}$, concluiu que o epídoto era estável apenas em um fundido de composição ácida nos experimentos a $8 \mathrm{kbar}$, e somente dentro de um intervalo de temperatura bastante estreito $\left(600^{\circ}-700^{\circ} \mathrm{C}\right)$. Ele identificou diversos campos de estabilidade nos quais o epídoto e o fundido coexistem com combinações de plagioclásio, homblenda, biotita, feldspato alcalino e vapor. Com base nessas observações, Naney (1983) concluiu que epídoto poderia ser uma fase magmática tardia.

Zen \& Hammarstron (1984) concluíram, com base nos dados experimentais de Naney (1983), que o epídoto de alguns plutões por eles estudados na Califórnia é possivelmente magmático. Eles usaram como evidência núcleos de allanita e a presença de inclusões de homblenda em epídoto, magmaticamente reabsorvidas.

Catorze análises de minerais do grupo do epídoto do Plutão de Terra Nova foram realizadas por microssonda eletrônica. Algumas análises representativas podem ser vistas na tabela 5. As características ópticas observadas, juntamente com os dados da química mineral, mostram que tanto zoisita como epídoto ocorrem no plutão de Terra Nova. Foi observada uma correlação entre o tipo de epídoto e sua característica textural;

Tabela 3 - Análise de núcleos de feldspatos alcalinos dos sienitos mesocráticos do plutão de Terra Nova Table 3 - Alkali-feldspar cores analyses of the mesocratic syenites from the Terra Nova Pluton

\begin{tabular}{|c|c|c|c|c|c|c|c|c|c|c|c|c|c|}
\hline AMOSTRA & 249-B & 249-B & 215-B & $216-\mathrm{B}$ & $21 \overline{6-B}$ & 2I1-B & $220-B$ & 205 & 213 & 215 & 210 & 210 & 201 \\
\hline GRAO & 5 & 6 & 5 & $\overline{2}$ & 4 & 8 & 8 & 3 & 6 & 6. & 6 & 8 & 4 \\
\hline $\begin{array}{l}\mathrm{SiO}_{2} \\
\mathrm{Al}_{2} \mathrm{O}_{3}\end{array}$ & $\begin{array}{l}64,140 \\
18,950\end{array}$ & $\begin{array}{l}64,280 \\
18,760\end{array}$ & $\begin{array}{l}64,010 \\
18,490\end{array}$ & $\begin{array}{l}63,090 \\
18,240\end{array}$ & $\begin{array}{l}63,420 \\
18,140\end{array}$ & $\begin{array}{l}64,930 \\
18,830\end{array}$ & $\begin{array}{l}64,620 \\
18,660\end{array}$ & $\begin{array}{l}63,770 \\
18,240\end{array}$ & $\begin{array}{l}64,520 \\
18,320\end{array}$ & $\begin{array}{l}64,070 \\
17,930\end{array}$ & $\begin{array}{l}63,050 \\
18,900\end{array}$ & $\begin{array}{l}65,050 \\
19,020\end{array}$ & $\begin{array}{r}64,080 \\
18,480\end{array}$ \\
\hline $\mathrm{CaO}$ &, 070 & 250 & 200 & $\sqrt{30}$ & 090 &, 100 & - & 190 & .150 & - & - & - & 220 \\
\hline $\mathrm{Na} 2 \mathrm{O}$ & 1,030 & 890 &, 740 & 940 & 1,010 &, 720 & 630 & 360 & 990 & .750 &, 670 & 3,530 &, 610 \\
\hline $\mathrm{K}_{2} \mathrm{O}$ & 15,100 & 15,440 & 15,340 & 15,700 & 15,880 & 16,010 & 16,350 & 15,840 & 15,300 & 15,780 & 15,970 & 11,670 & 16,070 \\
\hline $\mathrm{BHO}$ & 660 & 320 & 410 &, 670 &, 420 &, 410 & .700 & 940 & ,440 &, 800 & 1,330 & 380 & 680 \\
\hline Feo & $=$ & $=$ & - & $=$ & - & $\because$ & $=$ & 150 & $=$ & - & - & - & - \\
\hline TOTAL & 99,950 & 99,940 & 99,190 & 98,670 & 98,960 & 101,000 & 100,960 & 99,490 & 99,720 & 99,330 & 100,720 & 99,650 & 100,140 \\
\hline \multicolumn{14}{|c|}{ UNIDADES DE FORMULA MINERAL } \\
\hline Sï & 2,970 & 2,970 & 2,980 & 2,970 & 2,980 & 2,980 & 2,980 & 2,980 & 2,980 & 2,990 & 2,960 & 2970 & 2,980 \\
\hline Al & 1,040 & 1,020 & 1,020 & 1,010 & 1,000 & 1,010 & 1,010 & 1,005 &, 99 &, 986 & 1,030 & 1,030 & 1,010 \\
\hline 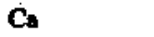 & ,004 & 012 & .010 &, 007 &, 004 &, 005 & 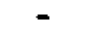 & 0,09 &, 007 & - & - & 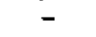 & 010 \\
\hline Na & ,090 & ,080 & .070 & ,076 & ,090 & ,064 & ,056 & ,032 & 089 & ,668 & .060 &, 310 & 060 \\
\hline $\mathbf{K}$ & 890 & 910 & 910 & 940 &, 950 & 940 & ,960 & 940 & 900 & .940 &, 950 &, 680 & 950 \\
\hline Ba &, 010 & ,006 &, 007 & ,012 & ,008 &, 007 &, 013 &, 017 &, 008 & 015 &, 024 &, 007 & 010 \\
\hline Fe & $=$ & $=$ & $=$ & 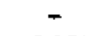 & - & 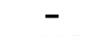 & &, 006 & 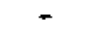 & & - & 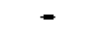 & - \\
\hline$A b$ & 9,150 & 7,980 & 7,070 & 7,770 & 8,650 & 6,370 & $\$, \$ 10$ & 3,260 & 8,920 & 6,750 & 5,970 & 35,450 & 5,880 \\
\hline An & 410 & 1,200 & 1,010 & 970 & - & 500 & - & 920 &, 700 & - & 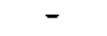 & - &, 980 \\
\hline Or & 90,450 & 90,820 & 92,920 & 91,260 & 91,350 & 93,130 & 94,490 & - & - & - & 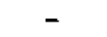 & - & $=$ \\
\hline C. & & & - & & & & & 95,820 & 90,380 & 93,250 & 94,030 & 68,550 & 93,140 \\
\hline
\end{tabular}


a zoisita é em geral anedral, e tende a ocorrer como grãos incluídos pelos feldspatos alcalinos, enquanto o epídoto é geralmente encontrado associado com minerais máficos.

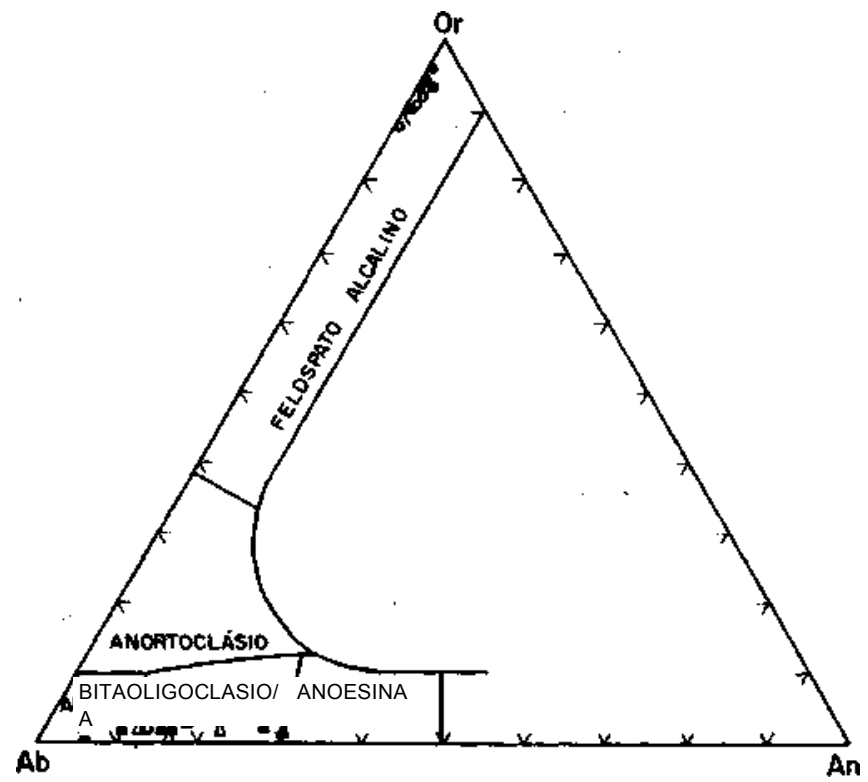

Figura $3 A$ - Variação compositional dos feldspatos das fádes leucocráticas. Feldspatos alcalinos - círculo cheio; núcleo-círculo aberto; borda. Plagioclásios - triângulo cheio; núcleo-triângulo aberto; borda

Figure 3A - Compositional variation of feldspar from the leucocratic facies. Alkali feldspar - filled circle; core - open circle; rim. Plagioclase - Filled triangle; core - open triangle rim
As associações minerais descritas por Zen \& Hammarstron (1984) não foram observadas no plutão de Terra Nova. Evidências petrográficas indicam que alguns dos cristais de epí-

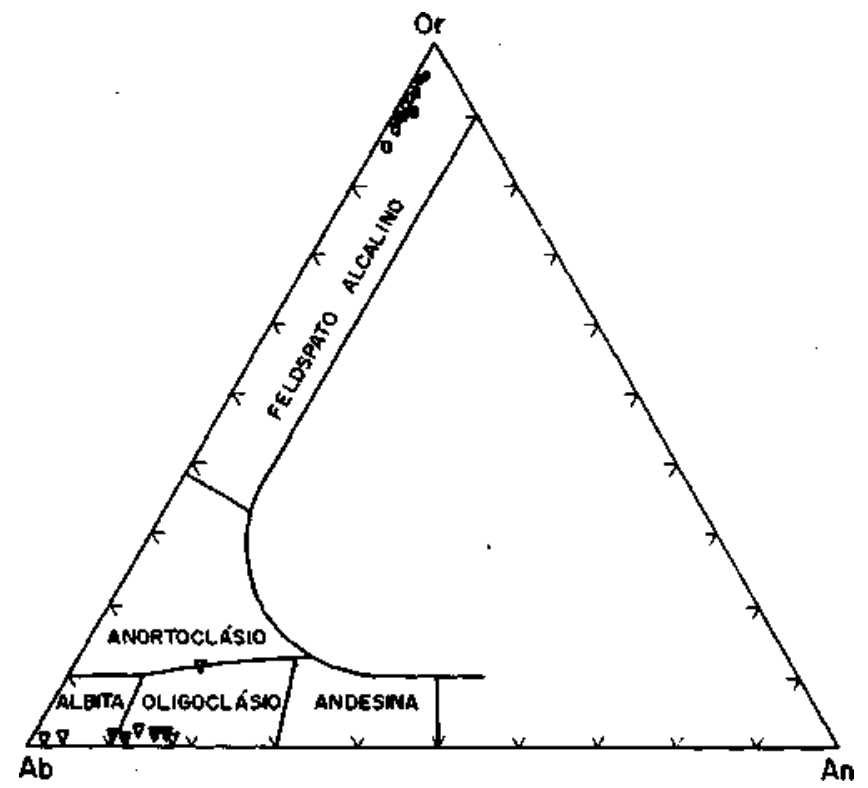

Figura 3B - Variação compositional de feldspatos dos sienitos mesocráticos. Feldspatos alcalinos - quadrado cheio; núcleo-quadrado aberto; borda. Plagioclásios - triângulo cheio invertido; núcleo-triângulo aberto invertido; borda

Figure 3B - Compositional variation of feldspars from the mesocratic syenites. Alkali feldspars - filled square; core - open square; rim. Plagioclases - filled inverted triangle; core - open inverted triangle; rim

Tabela 4 - Análises de núcleos de anfibólios cálcicos do plutão de Terra Nova

Table 4 - Analyses of calcic amphibole cores from the Terra Nova Pluton

\begin{tabular}{|c|c|c|c|c|c|c|c|c|c|c|c|c|c|c|c|}
\hline AMOSTRA & $\frac{\hbar}{216-B}$ & $\begin{array}{c}t \\
216-B \\
\end{array}$ & $\frac{\hbar}{240-B}$ & $\frac{\star}{240-B}$ & $\frac{*}{240-B}$ & 215-B & 249-B & 213 & 210 & 210 & 207-B & 211-B & 215-B & 215 & 205 \\
\hline GRAO & II & 10 & 2 & 3 & 4 & 2 & $\overline{3}$ & 4 & $\overline{2}$ & 4 & I1 & $I$ & 10 & 3 & 2 \\
\hline $\mathrm{SiO}_{2}$ & 51,29 & 48,54 & $53,4 !$ & 53,34 & 59,77 & 46,71 & 44,18 & 4,72 & 45,42 & 49,35 & 42,86 & 44,44 & 46,38 & 43,85 & 44,73 \\
\hline $\mathrm{Al}_{2} \mathrm{O}_{3}$ & 3,17 & 5,65 & 2,30 & 2,98 & 80 & 8,14 & 8,92 & 7,73 & 8,32 & 5,62 & 9,38 & 8,92 & 8,65 & 8,88 & 9,41 \\
\hline Feo & 12,26 & 14,54 & 11,63 & 12,57 & 9,50 & 14,87 & 17,40 & 16,39 & 17,47 & $15 ., 92$ & 17,98 & 18,29 & 15,12 & 16,96 & 18,88 \\
\hline $\mathrm{K}_{2} \mathrm{O}$ & 38 & 1,96 & 23 &, 27 & $\sqrt{2}$ & 96 & 1,15 & 98 & 97 & $\$ 5$ & 1,35 & 1,28 & 1,08 & 1,30 & 1,20 \\
\hline $\mathrm{Na} O$ & 94 & 98 & 87 &, 73 &, 79 & 1,85 & 1,76 & 1,65 & 1,88 & 1,41 & 1,82 & 2,01 & 1,84 & 2,22 & 1,39 \\
\hline $\mathrm{MoO}$ & 15,08 & 13,86 & 16,12 & 15,83 & 15,52 & 12,71 & 10,84 & 12,02 & 11,09 & 13,28 & 10,24 & 10,26 & 13,04 & 10,62 & 10,45 \\
\hline $\mathrm{CaO}$ & 12,22 & 10,32 & 12,37 & 12,45 & 11,94 & 11,67 & 11,70 & 11,53 & 11,55 & 11,74 & 11,37 & 11,50 & 11,70 & 11,33 & 12,04 \\
\hline $\mathrm{Cr}_{2} \mathrm{O}_{3}$ & .14 &, 00 &, 16 &, 02 &, 06 &, 13 &, 06 & 08 &, 00 &,$\infty 0$ & 00 &,$\infty 0$ & 08 & 00 &, 00 \\
\hline Mno & ,40 & ,47 & ,31 & ,33 & 34 & 20 & 38 & .44 & 54 & 44 & 38 &, 49 & .12 & 51 &, 35 \\
\hline $\mathrm{NiO}$ & .24 & $\infty 0$ & $\infty$ & $\infty$ & 00 & 03 &, 00 &, 12 &, 18 &, 00 & .10 & $\infty$ & 08 & .09 &, 17 \\
\hline $\mathrm{TiO}_{2}$ & 11 & 48 & 24 & 07 & , 10 & 96 & 1,20 & 1,17 & .48 & 45 & 1,54 & 1,28 & 86 & 1,94 & .75 \\
\hline TOTAL & 96,23 & 96,80 & 97,64 & 98,59 & 96,94 & 98,23 & 97,59 & 97,83 & 97,90 & $9 \overline{8}, 76$ & 97,02 & 98,47 & 99,07 & 97,70 & 99,37 \\
\hline \multicolumn{16}{|c|}{ UNIDADES DE FORMULA MINERAL } \\
\hline & 7,56 & 7,11 & 7,69 & 7,60 & 8,43 & 6,86 & 6,63 & 6,78 & 6,77 & 7,15 & 6,50 & 6,65 & 6,65 & $\overline{6,61}$ & 6,60 \\
\hline Al(4+) & 44 & 89 & $\mathbf{3 l}$ & 40 &, 00 & 1,15 & 1,37 & 1,22 & 1,23 & 85 & 1,50 & 1,35 & 1,25 & 1,39 & 1,40 \\
\hline TOTAL & 8,00 & 8,00 & 8,00 & 8,00 & 8,00 & 8,00 & 8,00 & 8,00 & 8,00 & 8,00 & 8,00 & 8,00 & 8,00 & 8,00 & 8,00 \\
\hline$A_{1}^{\prime}(6+)$ & .11 & .08 &, 08 & 10 &, 13 & .26 & .21 & .13 & .23 & .10 & .18 & .22 & 23 & 19 & 24 \\
\hline 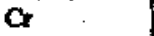 & .02 & $\infty$ &, 02 &, 00 &, 00 & 02 & ,01 & 01 &, 00 &, 00 &, 00 &, 00 & ,01 &, 00 &, 00 \\
\hline Feg & 1,41 & 96 & 1,32 & 1,26 & 1,99 & 1,53 & 1,79 & 1,52 & $1,7 !$ & 1,42 & 1,81 & 1,96 & 1,37 & 1,94 & 1,78 \\
\hline $\mathrm{Fe}$ &, 10 & 82 &, 08 & .24 &, 00 & 30 & $\$ 0$ & 51 & 47 & 52 & 47 & 33 & .47 & 20 & 55 \\
\hline $\mathbf{T}$ & .01 &, 05 &, 03 &, 01 &, 01 & ,1! &, 14 &, 13 &, 05 & .05 &, 18 & .14 & ,10 & 22 &, 08 \\
\hline & 3,31 & 3,03 & 3,46 & 3,36 & 3,26 & 2,78 & 2,42 & 2,66 & 2,47 & 2,87 & 2,31 & 2,29 & 2,82 & 2,39 & 2,30 \\
\hline $\mathrm{M}_{1}, \mathrm{M}_{2}, \mathrm{M}_{3}$ & 5,00 & 5,00 & 5,00 & 5,00 & 5,00 & 5,00 & 5,00 & 5,00 & 5,00 & 5,00 & 5,00 & 5,00 & 5,00 & 5,00 & 5,00 \\
\hline Mn & .05 & \$6 &, 04 & ;04 & $\$ 04$ &, 03 & ,05 & 06 &, 07 &, 05 &, 05 &, 06 &, 02 & 07 & 04 \\
\hline C. & 1,93 & 1,62 & 1,91 & 1,90 & 1,81 & 1,84 & 1,88 & 1,83 & 1,85 & 1,82 & 1,85 & 1,84 & 1,82 & $1, \mathbf{8 3}$ & 1,91 \\
\hline Ni & 03 &, 03 & $\infty$ & $\infty$ & 00 & 00 & 00 & 01 &, 02 &, $00^{\circ}$ & ,01 &, 00 & ,0I & 01 & 02 \\
\hline $\mathrm{N} \bullet$ (B) &, 07 & 28 &, 09 & ,10 & 20 & ,17 &, 12 & 17 & ,15 & .18 & .15 &, 16 & ,18 & 17 & .09 \\
\hline M4 & 2,00 & 2,00 & 2,00 & 2,00 & 2,00 & 200 & 2,00 & 2,00 & 2,00 & 2,00 & 2,00 & 2,00 & 2,00 & 2,00 & 2,00 \\
\hline $\mathbf{K}$ & .07 & 37 &, 04 & ;05 & ,02 &, 18 & 22 & , 19 &, 18 & , 10 & 26 & 25 & 20 & .25 & 23 \\
\hline N: & 27 & 28 & 24 & 20 & 22 & 53 & 51 & 48 & 54 & .40 & 54 & 58 & 52 & .65 &, 40 \\
\hline & 30 & .40 & 20 & 20 &,$\infty 0$ & so & 60 & ,50 &, 60 &, 30 &, 60 &, 70 & 30 & .70 & 50 \\
\hline $\mathrm{M}$ & 70 &, 76 & 72 &, 73 & ,62 &, 65 &, 58 & .64 & 59 & .67 &, 56 & 54 & .67 & .35 & 56 \\
\hline MINERAL & \multicolumn{5}{|c|}{ ACTINOLITA } & \multicolumn{5}{|c|}{ EDENTTA } & \multicolumn{5}{|c|}{ HORNALENDA EDENITICA } \\
\hline
\end{tabular}




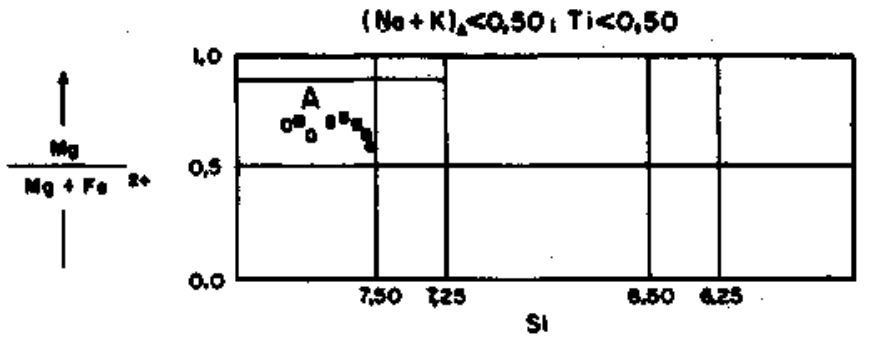

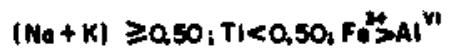
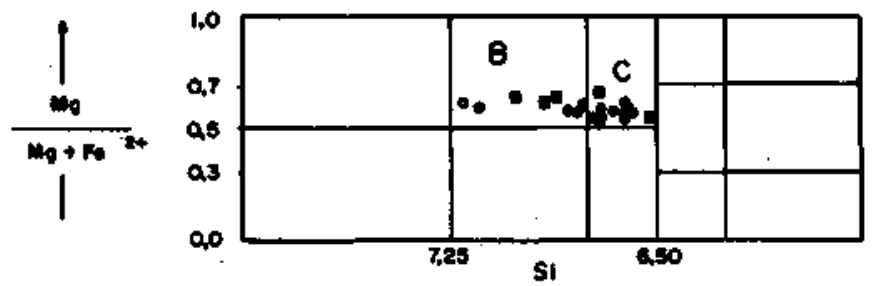

Figura 4 - Nomenclatura e composição dos anfibólios cálcicos do plutão de Terra Nova. A nomenclatura é de Leake (1978). Faties leucocráticas -círculo cheio; núcleo; círculo aberto; borda. Sienitos mesocráticos - quadrado cheio; núcleo - quadrado aberto; borda. A. Actinolita; B. Edenita; C. Hornblenda edenítica

Figure 4 - Composition and nomenclature for calcic amphiboles from the Terra Nova Pluton. After Leake (1978). Leucocratic facies - filled circle; core; open; circle rim. Mesocratic syenites - filled square; core; open square; rim. A. Actnolite; B. Edenite; C. Edenitic Homblenda

doto parecem ser anteriores aos feldspatos alcalinos e biotita. Eles parecem ser contemporâneos com alguns dos cristais de hornblendas, mas as evidências que apontam para uma origem magmática ou uma origem durante um estágio sub-sólidus são ainda inconclusivas. Desta forma, tentou-se obter uma estimativa geobarométrica para o plutão de Terra Nova a partir da composição química dos anfibólios.

GEOBAROMETRIA COM ANFIBÓLIOS Wones \& Gilbert (1981) sumarizaram aspectos da variabilidade química em anfibólios e outros silicates máficos como indicadores de variáveis intensivas em magmas graníticos. A composição dos anfibólios de dois plutões intrudidos a pequena profundidade e de três plutões com evidências de uma maior profundidade foram estudados por Hammarstron \& Zen (1986). Os anfibólios desses complexos são cálcicos, mas apresentam diferenças essenciais entre si no teor em Al, sendo o teor de Al total maior com uma maior profundidade de posicionamento da intrusão. Hammarstron \& Zen (1986) sugerem que as diferenças de teores de $\mathrm{Al}$ dos anfibólios cálcicos são diretamente relacionadas com a profundidade de intrusão dos plutões graníticos e podem, portanto, ser utilizadas como um geobarômetro. Dados de investigações experimentais proporcionam uma oportunidade para estudar o controle das variáveis intensivas na composição dos anfibólios cálcicos, e em particular o papel da pressão sobre o teor de Al nas hornblendas. Helz (1982) sumarizou estas relações em detalhe e concluiu que $\mathrm{SiO}_{2}$ e $\mathrm{Al}_{2} \mathrm{O}_{3} \mathrm{em}$ hornblenda não variam sistematicamente com a composição da rocha total, e que, quando apenas a pressão é considerada, o teor de $\mathrm{Al}^{6}$ na hornblenda aumenta com o aumento da pressão. Hammarstron \& Zen (1986) também mostraram que hornblenda formada a $3 \mathrm{kbar}$ de pressão ou menos, tem valores de $\mathrm{Al}$ total $<2,1$, enquanto hornblenda formada a $8 \mathrm{kbar}$ ou mais apresenta $\mathrm{Al}$ total $>2,0$. Os referidos autores enfatizam que esse método é empírico e que certos pré-requisitos devem ser atendidos antes desses dados serem aplicados a outros plutões. Desde que o teor $\mathrm{Al}^{4}$ na hornblenda é correlacionado negativamente com o teor de silica, os anfibólios devem coexistir com quartzo para eliminar a atividade de $\mathrm{SiO}_{2}$ como uma variável. A outra estimativa é

Tabela 5 - Análises de núcleos de epídoto do plutão de Terra Nova

Table 5 - Analyses of epidote cores from the Terra Nova Pluton

\begin{tabular}{|c|c|c|c|c|c|c|c|c|c|c|c|c|c|c|}
\hline AMOSTRA & 213 & 213 & $216-A$ & $216-A$ & 201 & 201 & 210 & 210 & 215 & 215 & 215 & 213 & 220-B & $220-\mathrm{B}$ \\
\hline GRAO & 2 & 5 & 1 & 1 & 2 & 3 & I & 1 & $I$ & 1 & 2 & 2 & I. & 1 \\
\hline $\mathrm{SiO}_{2}$ & 37,25 & 37,31 & 37,22 & 38,02 & 36,70 & 37,95 & 37,44 & 38,31 & 37,50 & 37,69 & 37,19 & $37, \overline{45}$ & 37,90 & 37,54 \\
\hline $\mathrm{Al}_{2} \mathrm{O}_{3}$ & 23,14 & 22,87 & 22,32 & 22,79 & 21,53 & 22,89 & 22,53 & 23,26 & 22,85 & 21,68 & 22,04 & 22,22 & 23,02 & 22,58 \\
\hline$F=04$ & 12,82 & 11,89 & 12,82 & 12,48 & 12,77 & 12,69 & 13,55 & 12,88 & 12,09 & 12,42 & 12,65 & 12,75 & 12,30 & 12,69 \\
\hline $\mathrm{CaO}$ & 23,15 & 22,69 & 22,76 & 2,83 & 22,97 & 23,70 & 23,09 & 23,05 & 22,74 & 22,26 & 22,51 & 22,80 & 23,09 & 22,43 \\
\hline Mno & - & - & - & - & $=$ & 30 & - & .26 & $=$ & 32 & - & - & 20 &, 12 \\
\hline $\mathrm{Ti}_{2}$ &, 30 & $=$ & 7 & $=$ & - &, 30 & - & $=$ & 31 & - & - & - &, 088 &, 13 \\
\hline $\mathrm{H}_{2} \mathrm{O}$ & .39 & 39 & 39 & , 40 & 38 & 40 & ,39 & 40 & ,39 & 39 & 39 & 39 & 39 & 39 \\
\hline TOTAL & 97,05 & 95,15 & 95,51 & 97,52 & 94,35 & 9823 & 97,00 & 98,16 & 95.88 & 9496 & 94,78 & 95,61 & 96,98 & 95,89 \\
\hline \multicolumn{15}{|c|}{ UNIDADES DE FORMULA MINERAL } \\
\hline$\overline{\operatorname{si}(4+)}$ & 2,97 & 3,02 & $3, \overline{0}$ & 3,02 & $\mathbf{3 , 0 2}$ & 3,00 & $\mathbf{2 , 9 9}$ & $\overline{3,02}$ & 3,02 & 3,09 & 3,03 & $\mathbf{3 , 0 3}$ & $\overline{3,02}$ & 3,03 \\
\hline$A \mid(4+)$ &, 03 & - & $=$ & . & . & .00 & ,01 & $=$ & - & - & - & - & - & - \\
\hline $\mathbf{Z}$ alte & 3,00 & 3,02 & 3,01 & 3,02 & 3,02 & 3,00 & 3,00 & 3,02 & 3,02 & 3,08 & 3,03 & 3,03 & 3,02 & 3,03 \\
\hline Al(6+) & 2,15 & 2,18 & 2,13 & 2,13 & 2,09 & 2,12 & 211 & 2,16 & 2,17 & 2,08 & 2,12 & 2,12 & 2,16 & 2,15 \\
\hline Fes & 85 & 81 &, 87 & 83 & 88 & 84 & ,90 & 85 & 81 & .84 &, 86 &, 86 & 82 & 85 \\
\hline Mng & - & - & - & 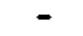 & - & - & 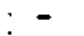 & - & - & - & - & - & 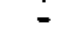 & 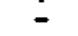 \\
\hline TI &, 02 & - & - & 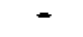 & - & .02 & - & - &, 02 & - & - & $=$ & - & $=$ \\
\hline$F_{z}$ &, 00 & - & $=$ & $=$ & $=$ & $=$ &, 00 &,$\infty$ & $=$ & - & - & - & - &, 00 \\
\hline Mnz & $=$ & $=$ & . & 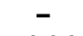 & $=$ & .02 & 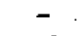 & ,01 & $=$ &, 02 & - & - & - & - \\
\hline $\mathbf{Y}$ & 3,02 & 2,99 & 3,00 & 2,96 & 2,96 & 3,00 & 3,02 & 3,01 & 3,00 & 2,94 & 2,98 & 2,98 & 299 & 3,00 \\
\hline $\mathrm{Mms}$ & - & - & - & - & - & - & - & - & - & - & - & - & $=$ & $=$ \\
\hline Mnz & - & - & - & - & $=$ & .00 . & - &, 01 & $=$ & .00 & - & - & - & - \\
\hline $\mathrm{Fe}_{2}$ &, 00 & . & - & 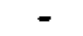 & - & - &,$\infty$ &, 00 & 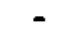 & - & - & - & - & $\mathbf{0 0}$ \\
\hline Ca & 1,98 & 1,97 & 1,97 & 2,03 & 2,02 & 2,00 & 1,98 & 1,94 & 1,96 & 1,94 & 1,97 & 1,98 & 1,97 & 1,94 \\
\hline Na & - & - & - & - & - & - & - & - & $=$ & - & - & - & - & $=$ \\
\hline $\mathbf{x}$ & 1,98 & 1,97 & 1,97 & 2,03 & 2,02 & 2,01 & 1,98 & 1,95 & 1,96 & 1,94 & 1,97 & 1,98 & 1,97 & 1,94 \\
\hline 0 & 12,00 & 12,00 & 12,00 & 12,00 & 12,00 & 12,00 & 12,00 & 1200 & 12,00 & 12,00 & 12,00 & 12,00 & 12,00 & 12,00 \\
\hline OH & 100 & 1,00 & 1,00 & 1,00 & 1,00 & 100 & $1, \infty 0$ & 1,00 & 1,00 & 1,00 & 1,00 & 1,00 & 1,00 & 1,00 \\
\hline TOTAL & 20,99 & 20,98 & 20,99 & 21,00 & 21,00 & 21,00 & 20,99 & 2098 & 20,97 & 2096 & 20,98 & 20,98 & 20,98 & 20,97 \\
\hline
\end{tabular}


que a paragênese deve incluir plagioclásio, feldspato alcalino, biotita, titanita e magnetita e/ou ilmenita, em adição à hornblenda e ao quartzo, de maneira que eles funcionem como um buffer. Os pré-requisitos acima discutidos são atendidos pela maioria das paragêneses que contêm anfibólios do plutão de Terra Nova.

As figuras $5 \mathrm{Ae} 5 \mathrm{~B}$, que foram idealizadas por Hammarstron \& Zen (1986), mostram os diagramas de $\mathrm{Al}^{4}$ versus $\mathrm{Al}$ total e da ocupação do sítio A versus $\mathrm{Al}^{4}$, respectivamente. A figura 5B mostra claramente que os anfibólios cálcicos do plutão de Terra Nova caem entre os campos para pressão baixa e para pressão intermediária de Hammarstron \& Zen (1986), enquanto a figura 5 A mostra que as amostras do plutão de Terra Nova caem no campo de baixa pressão. Utilizando-se a melhor equação de regressão linear, $\mathrm{P}=-3.93+5,03 \mathrm{Al}^{\mathrm{t}}$ (Hammarstron \& Zen 1986), a variação da pressão calculada foi determinada como sendo 1,2 kbar (pressão mínima) e 4,7 kbar (pressão máxima). A pressão média foi estimada em 3,7 kbar.

DISCUSSÕES E CONCLUSÕES O plutão de Terra Nova apresenta evidências de intrusão sob o controle de reativações do Lineamento Pernambuco, em condições de pressão média, durante o Proterozóico Superior. As evidências observadas, de ordem textural (1), de relações de campo (2), e de geobarômetros de epídoto (3) e de anfibólio (4), são discutidas a seguir.
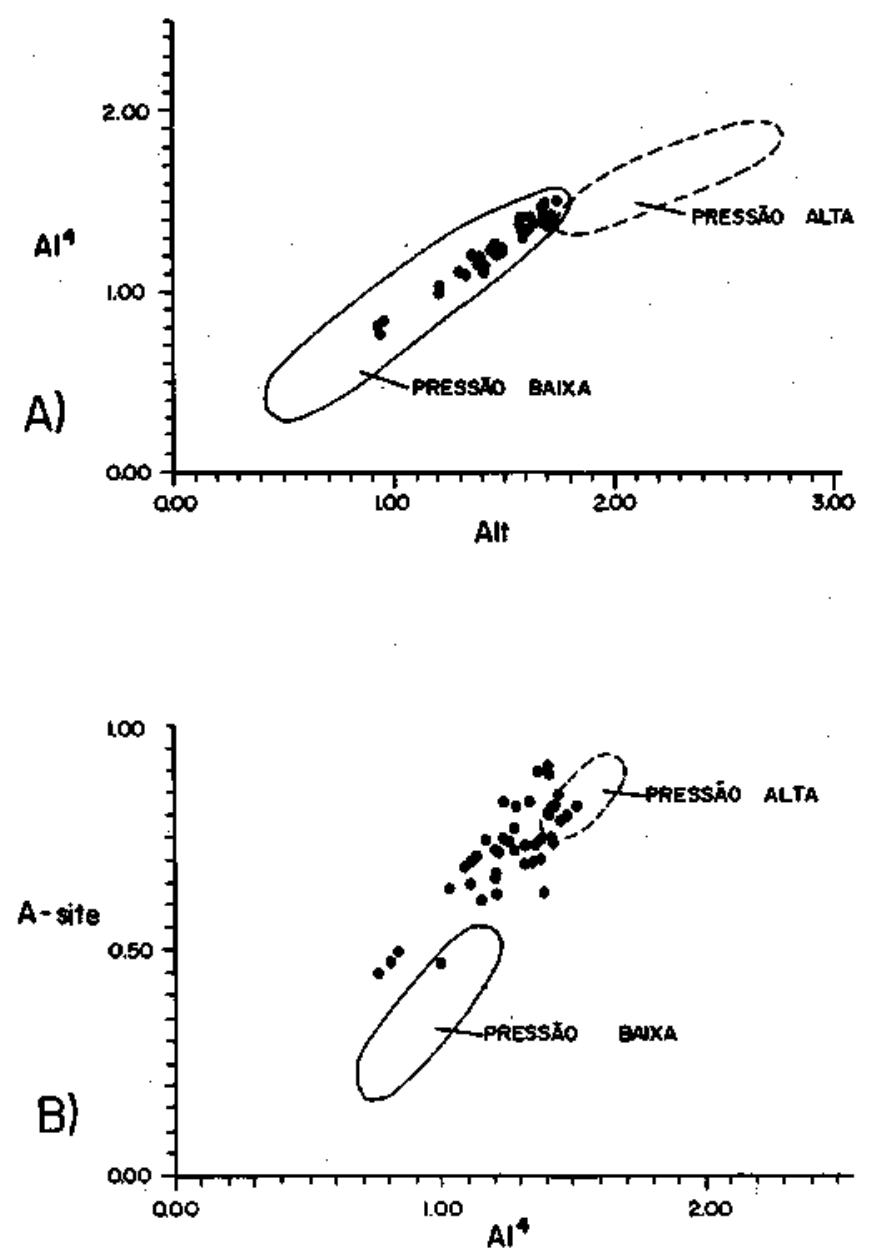

Figura 5 - Diagramas com dados de anfibólios cálcicos do plutão de Terra Nova. Os campos utilizados são de Hammarstron e Zen (1986). A. Diagrama $A l^{4}$ versus $A l_{\text {total }}=; \boldsymbol{B}$. Diagrama $\mathrm{Al}^{4}$ versus sitio $-\boldsymbol{A}$

Figure 5 - Diagrams with calcic atnphiboles with data from the Terra Nova Pluton. The fields after Hammarstron \& $\mathrm{Zen}$ (1986). A. $\mathrm{Al}^{4}$ versus $\mathrm{Al}_{\text {total }}\left(\mathrm{Al}^{4}\right.$ $+\mathrm{Al}^{6}$ ) diagram; B. $\mathrm{Al}^{4}$ versus $\mathrm{A}$ - site occupancy diagram
1.1. Deformação de fenocristrais Evidências macroscópicas indicam que as reativações atingiram seletivamente minerais que constituem o plutão, antes do resfriamento completo do mesmo. Estas evidências são caracterizadas pela ocorrência, no setor norte do plutão, de fenocristais de feldspato alcalino deformados e de fenocristais não-deformados numa escala de amostra de mão. Isto evidencia que, após a ocorrência de um evento deformativo, que atingiu parte dos fenocristais de feldspato alcalino já cristalizados, houve continuação da cristalização de feldspato alcalino, implicando que, durante a deformação, a rocha ainda estava se resinando, com cristais de feldspato alcalino em formação (havendo mais de $30 \%$ de fundido presente), e não poderia estar completamente cristalizada.

A deformação que atingiu parcialmente o setor norte do plutão de Terra Nova (o mais afastado do Lineamento Pernambuco) não chegou a originar uma foliação penetrativa, e sim um fluxo magmático provavelmente imposto pelo lineamento durante a cristalização do plutão, e que, portanto, não possui origem similar à foliação das rochas metamórficas encaixantes. Por outro lado, os fenocristais de feldspato alcalino não-deformados não incluem relíquias de uma xistosidade pretérita, excluindo a hipótese de que os mesmos tenham sido recristalizados metamorficamente após o evento deformativo a partir de um fenocristal pré-existente. Hutton (1988) descreveu e quantificou alguns casos de deformação que atingiram corpos de granitos do Donegal e da Groelândia durante a cristalização dos mesmos.

1.2. Diminuição de granulação A diminuição da granulação de uma rocha ígnea ou metamórfica por processos dinâmicos ligados aos falhamentos dúcteis, podendo levar à formação de milonitos e em casos extremos aos taquilitos, é um fato demonstrado por diversos autores e classicamente aceito. Caso a deformaçãp atinja a rocha ainda num estado plástico, $o$ registro de tal evento sob a forma de uma nítida foliação penetrativa dependerá da quantidade de material fundido ainda existente entre os cristais (A. Vauchez, comunicação verbal). Quando a quantidade de fundido entre os cristais é muito pequena, a deformação promove o atrito mútuo entre os cristais, produzindo a redução dos mesmos.

A diminuição gradativa da granulação dos fenocristais subedrais de feldspato alcalino e de hornblenda no plutão de Terra Nova, de norte para sul, coincidindo com a diminuição da distância entre as amostras analisadas e o Lineamento Pernambuco, reflete o controle estrutural imposto pelo lineamento durante a cristalização do plutão, e indica que o mesmo ao sofrer tal controle ainda estava em cristalização e dispunha de quantidade razoável de fundido entre os grãos.

A diminuição da granulação de rochas graníticas, no sentido núcleo-borda do corpo, originada durante os processos de intrusão e cristalização do mesmo, ocorre, em geral, de maneira brusca e próximo às bordas, formando a clássica carapaça (caracterizada por uma fácies de granulação fina). Esta feição tem sido aceita como relacionada ao resfriamento rápido do primeiro pulso magmático intrudido, ao entrar em contato corn a encaixante. Esta carapaça ocorre, em geral, de uma maneira aproximadamente simétrica em relação ao núcleo do corpo granítico, acompanhando total ou parcialmente o perímetro do mesmo. O plutão de Terra Nova é caracterizado por não possuir esta carapaça, nem uma assimetria da distribuição das fácies em relação ao núcleo do corpo. As principais características em termos da distribuição das fácies são descritas a seguir: a. Uma faixa estreita de sienitos muito grossos ocorre apenas ao longo de todo o contato norte, e possui contato gradativo com fácies adjacente.

b. Não ocorre no mesmo uma redução brusca da granulação, nas proximidades do contato com as encaixantes, em qualquer direção.

c. A redução da granulação ocorre gradativamente, apenas no sentido norte-sul, tendo aparentemente como eixo o Linea- 
mento Pernambuco, e não a partir do núcleo e em qualquer direção. O bordo sul é caracterizado por uma grande complexidade de relações de campo entre as fácies mapeadas, mas também não está caracterizado pela presença de granulação fina junto aos contatos. A ausência de fácies de granulação fina junto aos contatos poderia ser atribuída à obliteração total do mesmo devido ao aloctonismo.

Portanto, o plutão é caracterizado por uma grande assimetria na distribuição da granulação e das fácies, sugerindo, a partir dos dados disponíveis, que a origem de tal característica não foi apenas condicionada pela intrusão e cristalização do magma, mas também pelos eventos tectônicos ocorridos simultaneamente àqueles processos.

2. Inversão de relação de campo A fácies homblenda sienito fino, ora inclui, ora é incluída, pela fácies homblenda sienito grosso. Isto sugere que não havia estabilidade tectônica na área durante o processo de intrusão do plutão de Terra Nova. Caso houvesse estabilidade tectônica, seriam observadas relações de campo consistentes entre as duas fácies por todo o setor SW do plutão. esta complexidade e falta de consistência das relações de campo entre fácies só foi observada no setor SW do plutão, a região do plutão mais próxima do Lineamento Pernambuco.

3. Geobarômetro de epídoto $\mathrm{O}$ fato de o plutão de Terra Nova ocorrer próximo ao Lineamento Pernambuco, e de ter sido deformado tardiamente pelo mesmo, proporciona o aumento da complexidade das relações texturais observadas no epídoto.
No entanto, a petrografia revela a ocorrência de zoisita, de características claramente metamórficas, e de epídoto propriamente dito. O último, ora apresenta texturas de mineral primário, ora texturas de mineral secundário.

As paragêneses minerais descritas por Zen \& Hammarstron (1984) em granitóides de alta pressão da Califórnia não tem sido observadas no plutão de Terra Nova; o plutão de Terra Nova não pode ser considerado similar àqueles descritos por Zen \& Hammarstron (1984). Os cristais de epídoto identificados não possuem características texturais que indiquem de modo indiscutível uma origem primária. Portanto, não se pode considerar que o plutão de Terra Nova tenha se formado num ambiente de alta pressão apenas pela presença de epídoto na sua mineralogia.

4. Geobarômetro de anfibólio A geobarometria, com base na composição de anfibólio (Hammarstron \& Zen 1986), sugere que o plutão de Terra Nova foi intrudido a uma pressão entre 1,2 kbar (pressão mínima) e 4,7 kbar (pressão máxima). Ou seja, os dados do referido geobarômetro sugerem uma pressão entre baixa e intermediária. As referidas pressões têm sido interpretadas como, respectivamente: 1. Pressão baixa - considerada como um resultado de reações no estado sub-solidus, ou mesmo retrometamorflsmo, e desta forma não reflete as condições primárias de formação do plutão; 2. Pressão intermediária - considerada como o resultado mais próximo da realidade devido às características de mineral primário observadas nos cristais analisados.

\section{REFERÊNCIAS BIBLIOGRÁFICAS}

AFIFI, A.M. \& ESSENE, E.J. 1988. Minfile: a microcomputer program for storage and manipulation of chemical data on minerals. Am. Mineral 73:446-448.

ALMEIDA, F.F.M.; LEONARDOS, O.H.; VALENCA, J. 1967. Granitic rocks of NE South America. In: IUGS SYMPOSIUM ON GRANITES Recife, 1967. Proceedings... Recife, IUGS. p. 5-17.

BRITO NEVES, B.B. 1975. Regionalização geotectônica do Precambriano nordestino. São Paulo. 105 p. (Tese de Doutoramento, IG/USP).

BRITO NEVES, B.B.; VAN SCHMUS, W.R.; BASH, M.A.S. 1990. Contribuição ao estudo da evolução geocronológica do sistema de dobramentos Piancó - Alto Erigida. In: CONOR. BRAS. GEOL., 36. Natal, 1990. Anais... Natal, SBG. v. 6, p. 2697-2710.

CRAWFORD, M.L. \& HOLLISTER, L.S. 1982. Contrast of metamorphic and structural histories across the Work Channel lineament, coast plutonic complex, British Columbia. J. Geophys. Res., 87:3849-3860.

DEER, W.A.; HOWIE, R.A.; ZUSSMAN, J. 1966. An introduction to the rock-forming minerals. London, Longman. $528 \mathrm{p}$.

GUIMARÃES, IP · THOMPSON, R N · SILVA, A., F 1988. Bom Jardim intrusive complex: shoshonitic magmatism as evidence of collision tectonics during Upper Proterozoic times, NE Brazil. In: INT. CONF. GEOCH. EVOL. CONTIN. CRUST. Poços de Caldas, IAGqC/SBGq/IGUSP. p. 264-270.

HAMMARSTRON, J.M.; ZEN, E-An 1986. Aluminium in hornblende: an empirical igneous geobarometer. Am. Mineral, 71:1297-1313.

HELZ, R.T. 1982. Phase relations and compositions of amphiboles produced in studies of melting behaviour of rocks. Rev. Min., 9(B):279-146.

HUTTON, D.H.W. 1988. Granite emplacement mechanism and tectonic controls. Inferences from deformation studies. Trans. R. Soc. Edinburgh 79(2-3):245-256.

LEAKE.B.E. 1978. Nomenclature of amphiboles. Can. Minerai, 16:501-520.

LIMA, E.S. 1989. Evolução tectono-metamórfica durante o proterozóico do segmento mediano do domínio estrutural central, NE Brasileiro. Recife. 137 p. (Tese de Titulação, UFPE).

MARIANO, G. \& SIAL. A.N. 1988. Evidence of magma mixing b the Itaporanga Batholith, NE Brazil. Reconditi delia Societá Italiana di Mineralogia e Petrologia, 43(2):555-568.

NANEY, M.T. 1983. Phase equilibria of rock-forming ferromagnesian silicates in granitic systems. Am. J. Scl, 283:993-1033.

NARDI, L.V.S. 1986. As rochas granitóides da série shoshonítica. Rev. Bras. Geoc., 16(1):3-10.

PITCHER, W.S. \& BUSSEL, M.A. 1985. Andean dyke swarms: andesite in synplutonic relationship with tonalite. In: PITCHER, W.S.; COBBING,
E.J.; BECKINSALE, R.D. eds. Magmatism at a plate edge - The Peruvian Andes. Glasgow, Blackie Halsted Press, p. 102-107.

SIAL, A.N. 1984. Litogeoquímica de elementos terras raras na caracterização de granitóides do espaço Cachoeirinha, NE Brasil. In: CONGR. BRAS. GEOL., 33. Rio de Janeiro, 1984. Anais... Rio de Janeiro, SBG. p. 2697-2709.

SIAL, A.N. 1986. Granite-types b Northeast Brazil, Current knowledge. Rev. Bras. Geoc., 16(1): 10-20.

SIAL, A.N. 1987. Granitic rocks of northeast Brazil. In: ISGAM. Salvador, 1987. Extended abstracts... Salvador, SME/SGM - ORSTOM. p. 61-69.

SILVA, A., P.; THOMPSON, R.N.; LEAT, P. 1977. Petrology of Terra Nova pluton, Brazil, and associated ultrapotassic dykes. Rev. Bras. Geoc., 17(4):481-486.

SILVA, A., F.; THOMPSON, R.N.; GUIMARÃES. I.P. 1988. Petrology of late Brasiliano collision related ultrapotassic intrusive suite $\mathrm{b}$ the Terra Nova region, NE Brazil. In: INT. CONF. GEOCH. EVOL. CONTIN. CRUST. Poços de Caldas, IAGqC/SBGq/IGUSP. p. 258-263.

SILVA, A., P. 1989. Shoshonitic and ultrapotassic intrusive suites in the Piancó-Alto Brigida Belt, Pernambuco State, Brazil. London. $422 \mathrm{p}$. (PhD Thesis, University of London).

SILVA, M.A., P. 1985. Projeto Cachoeirinha: relatório final Recife, CPRM V. 1,128 p. (Rel. Int.).

STRECKEISEN, A. 1976. To each plutonic rock its proper name. Earth Sci. Rev. 12:1-33.

THOMPSON, R.N. \& FOWLER, M.B. 1986. Subduction-related shoshonite magmatism: a study of Siluro-Ordovician syenites from the Scottish Caledonides. Contrib. Mineral Petrol, 94:507-522.

WHITNEY, J.A.; JONES, L.M.; WALKER, R.L. 1976. Age and origin of the Stone Mountain Granite, Lithonia district, Georgia. Geol Soc. Am. Bull, 87:1067-1077.

WONES, D.R. \& GILBERT, M.C. 1981. Amphiboles in the igneous environment. Rev. Min., 9(B):355-390.

ZEN, A-En; HAMMARSTRON, J.M. 1984. Magmatic epidote and its petrologic significance. Geology, 12:515-518.

ZORPI, M.J.; COULON, C.; ORSINI, J.B.; COCIRTA, C. 1989. Magma mingling zoning and emplacement b calc-alkaline granitoid plutons. Tectonophysics, 157:315-329.

MANUSCRITO A650 Recebido em 19 de março de 1990 Revisão do autor em 5 de fevereiro de 1991 Revisão aceita em 5 de fevereiro de 1991 